\title{
Capsule Commentary on Reese et al., Two Randomized Controlled Pilot Trials of Social Forces to Improve Statin Adherence Among Patients with Diabetes
}

\author{
Maria K. Wolters, Dr. phil. Dipl-Inform \\ Informatics \& Psychology, , University of Edinburgh, Edinburgh, UK.
}

J Gen Intern Med 31(4):416

DOI: $10.1007 / \mathrm{s} 11606-016-3599-0$

(c) The Author(s) 2016. This article is published with open access at Springerlink.com each arm could have helped clarify to what extent those effects might have been present. It would also have provided valuable data on the participants' motivation for taking part in the study, and highlighted the extent to which the study itself might have been a valuable social force.

Corresponding Author: Maria K. Wolters, Dr. phil. Dipl-Inform; Informatics \& Psychology, University of Edinburgh, Edinburgh, UK (e-mail: Maria.wolters@ed.ac.uk).

Compliance with Ethical Standards:

Conflict of Interest: The author has no conflict with any of the material in this manuscript.

Open Access This article is distributed under the terms of the Creative Commons Attribution 4.0 International License (http:// creativecommons.org/licenses/by/4.0/), which permits unrestricted use, distribution, and reproduction in any medium, provided you give appropriate credit to the original author(s) and the source, provide a link to the Creative Commons license, and indicate if changes were made.

\section{REFERENCES}

1. Ioannidis JPA. Why most published research findings are false. PLoS Med. 2005;2:124. doi:10.1371/journal.pmed.0020124.

2. Reese PP, Kessler JB, Doshi JA, Friedman J, Mussell AS, Carney C, Zhu J, Wang W, Troxel A, Young P, Lawnicki V, Rajpathak S, Volpp K. Two randomized controlled pilot trials of social forces to improve statin adherence among patients with diabetes. J Gen Intern Med. 2015. doi:10.1007/ s11606-015-3540-y.

3. Greenhalgh $\mathbf{T}$, Howick $\mathbf{J}$, Maskrey N. Evidence based medicine: a movement in crisis? BMJ. 2014;348:g3725.

4. De Amici D, Klersy C, Ramajoli F, Brustia L, Politi P. Impact of the hawthorne effect in a longitudinal clinical study. Control Clin Trials. 2000;21:103-14.

5. Haynes RB, Ackloo E, Sahota N, McDonald HP, Yao X. Interventions for enhancing medication adherence. Cochrane Database Syst Rev. 2008;16(2):CD000011.

This comment refers to the article available at: $h t t p: / / d x$.doi.org/10.1007/ s11606-015-3540-y.

Published online February 18, 2016 